\title{
Cross-Sectional Household Survey of Risk Behaviors Related to Viral Hepatitis among Adults in Sokoto-Nigeria
}

\author{
Shuaibu A. Hudu and Nabil S. Hamal
}

\section{ABSTRACT}

Background: Viral hepatitis is a deadly disease which can manifest as acute, chronic, hepatocellular carcinoma, and liver failure and responsible for 1.34 million deaths globally, a number comparable to deaths caused by tuberculosis and higher than those caused by HIV.

Objectives: The goal of this survey was to find the vastness of different risk factors associated with Viral Hepatitis and to describe the connection between these risk and sociodemographic factors among adults in Sokoto-Nigeria.

Methods: This cross-sectional survey was carried in nine local government areas in the state. A two-stage cluster sampling was utilized and adults who were living in the selected household were interviewed. A multivariate linear regression model was used to evaluate the relationship between sociodemographic indicators and different viral hepatitis risk factors.

Results: Seven hundred and twenty eight respondents were recruited for this survey. Sharing nail cutters, body piercing, and razor blade use were the most pervasive risk factors among respondents. Males, married couples, respondents somewhere in the range of 27 and 40 years of age, and people with low educational achievement were more likely to be exposed to risk factors associated with Viral Hepatitis.

Conclusion: The risk of viral hepatitis was moderately high among the survey subject. Consequently, explicit projects like forum, classes and persistent instruction on preventive measures for viral hepatitis ought to be custom fitted to these forums. These projects could be directed by government specialists like the Ministry of Health Sokoto and other support agencies and non-governmental organizations.

Keywords: viral hepatitis, Risk factors, Sokoto, Nigeria.

Submitted : May 20, 2021

Published : June 12, 2021

ISSN: 2593-8339

DOI: 10.24018 /ejmed.2021.3.3.883

\section{S. A. Hudu*}

Department of Medical Microbiology and Parasitology, Faculty of Basic Clinical Sciences, College of Health Sciences, Usmanu Danfodiyo University Sokoto, 840232 Sokoto State, Nigeria.

(e-mail: hudu.shuaibu@udusok.edu.ng)

N. S. Hamal

Department of Microbiology, Faculty of Medicine, Asia Metropolitan University, 81750 Johor Bahru, Malaysia; Department of Medical Microbiology, Faculty of Medicine and Health Sciences, Sana'a University, Sana'a, Yemen.

(e-mail: nabil.harmal@gmail.com)

*Corresponding Author

\section{INTRODUCTION}

Viral hepatitis $(\mathrm{VH})$ is an expanding global health issue and different hepatitis infections (A, B, C, D, and E infections) have been ensnared. While Hepatitis A (HAV) and hepatitis $\mathrm{E}(\mathrm{HEV})$ are continuous reasons for intense irregular diseases and episodes, Hepatitis B (HBV) and hepatitis $\mathrm{C}(\mathrm{HCV})$, usually prompts chronic infection that can confound to liver cirrhosis or hepatocellular carcinoma in the absence of intervention [1]. Universally, around 257 million people are living with persistent hepatitis B (CHB) and 71 million individuals with hepatitis $\mathrm{C}$. In sub-Saharan Africa, around 60 million individuals are assessed to have chronic hepatitis $\mathrm{B}$ infection while, 10 million more have persistent hepatitis $\mathrm{C}$ viral disease [2], [3]. There are two major routes of viral hepatitis $(\mathrm{VH})$ transmission: vertical transmission and flat transmission. Vertical transmission of viral hepatitis happens basically in profoundly endemic zones, while flat transmission is the fundamental driver of infection in lowendemic areas [4], [5].
Several risk factors for even transmission have been distinguished, for example, history of dental methods or careful interventions, blood transfusions, hemodialysis, and history of scraped spots during haircuts [6]. A certain group additionally has a higher risk of $\mathrm{VH}$ for instance men who have intercourse with men, medication, and razor blade users medical care workers, family individuals who live with a $\mathrm{VH}$ carrier, and people with numerous sexual partners [7], [8]. Furthermore, VH infection pervasiveness is higher among individuals who having been tattooed, who have piercings, and who share family apparatuses like toothbrushes, extremely sharp edges, and nail cutters [9]. The frequency of hepatocellular carcinoma in the African continent is expanding because of rising prevalence of viral hepatitis infections. These discoveries propose that African populaces from region endemic for viral hepatitis are at considerable danger of hepatocellular carcinoma. In Nigeria age over 30 years, multiparty, been independently employed, non-tertiary training, helpless information, absence of immunization, sharing sharps and counselling quacks for obtrusive strategies 
have been featured to be related with HBV predominance. However, age lesser than 20 years had critical association with HCV prevalence [10]. This survey aimed to recognize the extent of $\mathrm{VH}$ risk factors and the association between sociodemographic determinants and the risk factors among adults in Sokoto-Nigeria.

\section{Methodology}

\section{A. Study Design and Setting}

A cross-sectional survey was conducted in nine local government areas of Sokoto state between 18 January and 14 May 2020 where 768 subjects were recruited. The convention utilized in this survey was affirmed by the Ministry of Health Ethics committee, Sokoto. Informed consent was gotten from all subjects preceding enrolment.

\section{B. Sampling Technique}

A stratified two-stage cluster random sampling was utilized to enlist the subjects. Momentarily, 1,575,200 families in Sokoto were isolated into 16,562 enumeration blocks in nine local government areas and every enumeration block comprised of 80 and 120 living quarters. 59 enumeration blocks $\mathrm{s}$ for metropolitan zones and 5 enumeration blocks $\mathrm{s}$ for rural areas and 12 living quarters inside every EB were arbitrarily chosen. Altogether, 768 living quarters were examined (708 living quarters for metropolitan and 60 living quarters for rustic zones) and one person, who was Sokoto and at least 20 years of age, was chosen from each living quarters.

\section{Data Collection}

Physical interviews were led at chosen families via trained enumerators. The meetings were conducted in Hausa or English. Subjects who could not understand English and Hausa were attended by interpreters who had the option to convey and make an interpretation of the survey into their favored language. If the subjects were missing over several days, a neighbor who clung to the qualification models, with a comparable race as the recently chosen member was chosen all things considered. Before the meeting, an outline of the points and advantages were given to the subjects, and, for the individuals who consented to take part, verbal or composed educated assent was acquired. Preceding asking the member inquiries, questioners gave the subjects a pamphlet from the Ministry of Health Sokoto which contained photos, side effects of $\mathrm{VH}$ infection, and data on the transmission of $\mathrm{VH}$, and anticipation techniques for $\mathrm{VH}$.

\section{Instrument of Data Collection}

A published questionnaire was adopted from a past study and translated to the Hausa language [11]. Both the English and Hausa version of the questionnaire was assessed by a board of three clinical specialists wherein phrasing and construction of a portion of the inquiries were updated. The re-vised adaptations of the two forms of the questionnaire were at first tried among 121 respondents. This pilot study uncovered that addresses identified with risk conduct had great inward consistency. During this pilot test, the respondents were likewise approached to give input, which was considered the last form of the questionnaire.

\section{E. Study Variables}

The fundamental result variable in this survey was a bunch of risk factors for $\mathrm{VH}$ that was identified with family individuals' way of life. Eleven way of life-related conduct risk factors were chosen as result variable in this survey which were the most pertinent to Sokoto: sharing needles, sharing extremely sharp steels, sharing a toothbrush, sharing a nail shaper, tattoos, body-penetrating, needle therapy, sex with an obscure individual, more than 10 sexual accomplices, razor blade use and jail insight. The questions identified with risk factors were all on a seven-point Likert scale, 1 for "never" and 7 for "every time". Illustrative factors for this survey included sexual orientation, identity, instruction, and age. During the meeting, the identity of the subjects was recorded and afterward gathered into Hausa, Ibo, Yoruba, and others. Educational achievement was characterized as the most elevated level of formal training finished and was ordered into the accompanying classes: ignorant, grade school, optional school, recognition, certificate, and postgraduate. The date of birth was recorded during the meeting, changed over into real age, and separated into three groups (20-26, 27-40, and 41-54 years of age).

\section{F. Data Analysis}

A linear regression model was used to demonstrate the relationship between segment factors and risk factors for $\mathrm{VH}$ infection. Separate models were built for each of the 11 risk factors considered. Before leading the relapse survey, a few demonstrative checks were performed on how well the information met suspicions of a direct relapse model, including a multicollinearity test (fluctuation swelling factor, less than 5), a heteroscedasticity test (White test, p-value greater than 0.05), a sequential auto-relationship test (Lagrange multiplier, p-value greater than 0.05), and an ordinariness test (Jarque-Bera test, p-value greater than 0.05). Our indicative outcomes uncovered no infringement in straight relapse presumptions. All surveys were conducted utilizing the IBM SPSS measurements adaptation 22.0.

\section{RESUlTS}

\section{A. Participant Characteristics}

Seven hundred and sixty-eight families were interviewed, and 40 reactions were avoided because of deficient data. 728 $(94.7 \%)$ subjects were included in the final analysis. The greater parts $(54.5 \%)$ of subjects were male and the mean age of respondents was 40 years $(\mathrm{SD} \pm 11.0)$. Most respondents were Hausa, then Ibo, and Yoruba (Table I).

\section{B. Viral Hepatitis Risk Behavior}

The most widely recognized high-risk factors were sharing nail cutters (82.4\% did infrequently or all the more regularly), body puncturing (34.9\% announced a worth of seldom or all the more frequently), razor blade use $(20.1 \%$ did once in a while or all the more regularly) and going through needle therapy $(15.7 \%$ did seldom or all the more regularly). The prevalence of risk factors ( $\%$ of those participating in conduct once in a while or all the more regularly) changed by sexual orientation. Among males, the two most basic risk factors were sharing nail cutters and razor blade use, though the two most basic risk factors were sharing nail cutters and body 
puncturing for females (Table II).

TABLE I: DEMOGRAPHIC CHARACTERISTICS OF PARTICIPANTS $(\mathrm{N}=728)$

\begin{tabular}{lc}
\multicolumn{1}{c}{ Variables } & Frequency $(\%)$ \\
\hline Age in years (mean \pm SD) & $40 \pm 11.0$ \\
Sex & \\
Male & $397(54.5)$ \\
Female & $331(45.5)$ \\
Ethnicity & \\
Hausa & $439(60.3)$ \\
Ibo & $170(23.4)$ \\
Yoruba & $116(19.9)$ \\
Others & $3(0.4)$ \\
Occupation & \\
Private employee & $214(29.4)$ \\
Self-employment & $175(24.0)$ \\
Civil servant & $96(13.2)$ \\
Retired & $53(7.3)$ \\
Student & $26(3.6)$ \\
Others & $19(2.6)$ \\
Unemployed & $145(19.9)$ \\
Marital status & \\
Single & $139(19.1)$ \\
Married & $574(78.8)$ \\
Widowed & $9(1.2)$ \\
Divorced & $6(0.8)$ \\
Education & $36(5)$ \\
Primary & $342(37)$ \\
Secondary & $188(25.8)$ \\
Diploma & $23(16.9)$ \\
Degree & \\
Postgraduate & \\
\hline deviation & \\
\hline
\end{tabular}

SD: Standard deviation.

C. Association of Sociodemographic Factors and Viral Hepatitis Risk Behavior

A linear regression model analyzed the association between sociodemographic elements and $\mathrm{VH}$ risk factors. Being male was altogether connected with various openings, including Sharing needles, sharing extremely sharp edges, sharing toothbrushes, tattoos, sex with multiple partners, and razor blade use. Being married was altogether connected with two openings: sharing toothbrushes and sharing nail cutters. Respondents aged 41 and 54 had comparable risks to those older, but on the other hand, were bound to share nail cutters. Contrasted with those with a college degree, respondents with a lower educational background had more serious risk factors of sharing nail cutters and utilizing razor blades (Table III).

\section{DISCUSSION}

The results in this survey were a bunch of risk factors for $\mathrm{VH}$ infection that were identified with family individuals' way of life. We chose notable risk factors that are generally pertinent to Sokoto. Needling sharing has for some time been recognized as a risk factor and because of its significant role in $\mathrm{VH}$ transmission, $\mathrm{VH}$ can persist outside the body for at least seven days, and, during this period, sharing contaminated extremely sharps, toothbrushes and nail cutters are critical risk factors in transmitting $\mathrm{VH}$ among family members. Studies likewise affirm that these tools are repositories of viral hepatitis and they have been accounted for as a source of $\mathrm{VH}$ transmission in a $\mathrm{VH}$ infection outbreak [12]. Previous studies show that tattooing and bodypenetrating are risk factors for $\mathrm{VH}$ transmission, and in the previous twenty years, it has been attested that needle therapy is an autonomous risk factor for VH infection [12]-[14]. It is likewise notable that $\mathrm{VH}$ could be communicated through sex and consequently perilous sexual practices are a risk factor for VH infection. Such works incorporating sexual exercises with different accomplices and with somebody with obscure VH status [15].

The WHO has advanced an objective to wipe out VH and $\mathrm{C}$ by 2030 [16]. However, because of a high prevalence of $\mathrm{VH}$ infection persistent carrier status and an immunization program that is restricted to new-born, Sokoto is probably going to remain exceptionally endemic for $\mathrm{VH}$ sooner rather than later. Thought of the appropriation of risk factors identified with VH infection in the populace can better inform efforts to target screening and immunization programs. In this paper, we inspected the socio-segment, or individual-based, risk factors identified with VH disease. BG Link and J Phelan [17] have contended that individual-based risk variables ought to be focused on improving medical issues all in all. In this survey, we center around sexual orientation, identity, training, and age.

TABLE II: DESCRIPTIVE STATISTIC OF HEPATITIS B RISK BEHAVIOR (N=728)

\begin{tabular}{|c|c|c|c|c|c|c|c|}
\hline Risk Behavior & $\begin{array}{l}\text { Never } \\
\mathrm{n}(\%)\end{array}$ & $\begin{array}{c}\text { Rarely } \\
\mathrm{n}(\%)\end{array}$ & $\begin{array}{c}\text { Occasionally } \\
\text { n }(\%)\end{array}$ & $\begin{array}{c}\text { Sometimes } \\
\mathrm{n}(\%)\end{array}$ & $\begin{array}{c}\text { Frequently } \\
\mathrm{n}(\%)\end{array}$ & $\begin{array}{c}\text { Usually } \\
\mathrm{n}(\%)\end{array}$ & $\begin{array}{c}\text { Every time } \mathrm{n} \\
(\%)\end{array}$ \\
\hline Sharing needles & 718 (98.6) & $7(1.0)$ & $0(0.0)$ & $3(0.4)$ & $0(0.0)$ & $0(0.0)$ & $0(0.0)$ \\
\hline Sharing razors & $658(90.4)$ & $38(5.2)$ & $7(1.0)$ & $5(0.7)$ & $6(0.8)$ & $7(1.0)$ & $7(1.0)$ \\
\hline Sharing toothbrushes & $629(86.4)$ & $46(6.3)$ & $20(2.7)$ & $5(0.7)$ & $4(0.5)$ & $18(2.5)$ & $6(0.8)$ \\
\hline Sharing nail cutters & $128(17.6)$ & $31(4.3)$ & $47(6.5)$ & $63(8.7)$ & $69(9.5)$ & $90(12.4)$ & $300(41.2)$ \\
\hline Tattooed & $671(92.3)$ & $28(3.9)$ & $8(1.1)$ & $1(0.1)$ & $8(1.1)$ & $4(0.6)$ & $7(1.0)$ \\
\hline Body piercing & $473(65.1)$ & $104(14.3)$ & $38(5.2)$ & $28(3.9)$ & $25(3.4)$ & $20(2.7)$ & $39(5.4)$ \\
\hline Undergoing acupuncture & $614(84.3)$ & $34(4.7)$ & $20(2.7)$ & $15(2.1)$ & $19(2.6)$ & $20(2.7)$ & $6(0.8)$ \\
\hline Sex with multiple partners & 695 (95.6) & $8(1.1)$ & $2(0.3)$ & $1(0.1)$ & $3(0.4)$ & $6(0.8)$ & $12(1.7)$ \\
\hline Alcohol use & $576(79.1)$ & $23(3.2)$ & $37(5.1)$ & $35(4.8)$ & $20(2.7)$ & $22(3.0$ & $13(2.1)$ \\
\hline
\end{tabular}

TABLE III: ASSOCIATION BETWEEN SOCIODEMOGRAPHIC VARIABLES AND HEPATITIS B RISK BEHAVIORS (N = 728)

\begin{tabular}{|c|c|c|c|c|c|c|c|}
\hline Variables & $\begin{array}{l}\text { Sharing } \\
\text { Needles }\end{array}$ & $\begin{array}{c}\text { Sharing razor } \\
\text { Blades }\end{array}$ & $\begin{array}{c}\text { Sharing } \\
\text { Toothbrush }\end{array}$ & $\begin{array}{c}\text { Sharing } \\
\text { nail cutter }\end{array}$ & Tattoos & $\begin{array}{c}\text { Body } \\
\text { piercing }\end{array}$ & $\begin{array}{c}\text { Sex with multiple } \\
\text { Partners }\end{array}$ \\
\hline Male & $0.076 * * *$ & $0.100 * * *$ & $0.071^{*}$ & 0.018 & $0.079 * * *$ & $-0.404 * * *$ & $0.070 *$ \\
\hline \multicolumn{8}{|l|}{ Ethnicity } \\
\hline Ibo & 0.018 & $-0.535^{* * *}$ & 0.124 & 0.044 & -0.105 & -0.051 & 0.088 \\
\hline Hausa & 0.022 & $-0.572 * * *$ & 0.207 & 0.131 & -0.330 & -0.168 & 0.113 \\
\hline Yoruba & 0.100 & $-0.454 * * *$ & 0.115 & 0.014 & -0.113 & 0.059 & 0.052 \\
\hline $\begin{array}{l}\text { Married vs. not } \\
\text { Age }\end{array}$ & -0.021 & -0.030 & $0.098 * * *$ & $0.127 * * *$ & 0.031 & 0.052 & $0.079 *$ \\
\hline $20-26$ & -0.052 & 0.048 & 0.068 & $0.185^{* * *} *$ & 0.055 & $0.074 * *$ & 0.052 \\
\hline $27-40$ & -0.024 & $0.128 * * *$ & $0.148 * * *$ & $0.310^{* * * *}$ & $0.167 * * *$ & $0.133^{* * *}$ & 0.034 \\
\hline $41-54$ & -0.006 & 0.053 & 0.038 & $0.172 * * *$ & 0.086 & 0.052 & 0.073 \\
\hline $\begin{array}{l}\text { University degree } \\
\text { vs not }\end{array}$ & 0.015 & 0.055 & 0.019 & $0.121 * * *$ & 0.024 & -0.015 & 0.010 \\
\hline
\end{tabular}


The WHO has advanced an objective to wipe out VH and $\mathrm{C}$ by 2030 [16]. However, because of a high prevalence of $\mathrm{VH}$ infection persistent carrier status and an immunization program that is restricted to new-born, Sokoto is probably going to remain exceptionally endemic for $\mathrm{VH}$ sooner rather than later. Thought of the appropriation of risk factors identified with $\mathrm{VH}$ infection in the populace can better inform efforts to target screening and immunization programs. In this paper, we inspected the socio-segment, or individual-based, risk factors identified with VH disease. BG Link and J Phelan [17] have contended that individual-based risk variables ought to be focused on improving medical issues all in all. In this survey, we center around sexual orientation, identity, training, and age.

Past surveys in different nations have likewise discovered a connection between VH risk factors and sociodemographic status. As early as 1990, BA Koblin, J Mccusker, BF Lewis and JL Sullivan [18] found that VH risk conduct relied upon identity. In later years, a survey demonstrated that males are bound to be presented to certain risk factors, for example, different sexual accomplices and razor blade consumption [19]. In another survey, sharing different family items, having tattoos, and having risky sexual between course was more probable in males, and every one of these practices expanded the risk of VH disease [20]-[22]. Another study tracked down that the circulation of risk factors differed across ages [23]. The transmission examples of VH inside a local area shift generally between nations, which can impact the segment appropriation of risk factors. In the United States, VH alongside other blood-borne diseases like HIV is frequently communicated through infusion drug use, and infusion drug use is more normal among more youthful ages [24], [25].

This survey uncovers that the most widely recognized risk factors identified with $\mathrm{VH}$ were sharing nail cutters, having body piercings, utilizing razor blades, and going through needle therapy. The risk factors inspected in this survey depended on hypothetical concerns and have been researched in past epidemiological surveys. A previous study revealed that sharing different family things expanded the risk of $\mathrm{VH}$ infection [20]. More explicitly, a survey led in Northern Brazil showed VH transmission through a nail clipper [26]. However, another survey led in Egypt discovered no proof of sharing nail cutters being a significant method for $\mathrm{VH}$ transmission [27]. Body puncturing, moderately normal risk conduct, particularly among ladies in this survey, has additionally been connected to VH infection. In Bangkok, little youngsters with ear piercings had a higher possibility of $\mathrm{VH}$ infection [28], and Brazilian teenagers found that body penetrating was a source of VH transmission [26]. Similarly, in Nigeria ear and nose piercing mostly practice by females has been identified as a risk factor for transmitting viral hepatitis [29]-[31].

Overall, our findings demonstrate that risk factors of $\mathrm{VH}$ infection are moderately high among the surveyed populace, especially males, more youthful and moderately aged grownups, and those with a lower education level. To decrease risk factors among these groups, explicit projects like discussions, workshops, and constant educational programs on preventive measures are required. These counteraction measures could be led by the Ministry of Health in conjunction with the Ministry of Women Affairs, Ministry of information as well as community organizations. The group with the most risk factors was of reproductive age. Along these lines, $\mathrm{VH}$ infection counteraction measures should include $\mathrm{VH}$ screening would lessen the pace of maternal transmission of $\mathrm{VH}$ to newborns. Extended screening and immunization programs in government clinics ought to be committed to these risk groups. Viral Hepatitis immunization to postpregnancy moms that are susceptible to $\mathrm{VH}$ infection ought to be underscored while their mates and relatives ought to be evaluated for $\mathrm{VH}$ infection status if they are HBsAg positive during antenatal screening. Further preventive activities can be consolidated into educational messages to these groups, for example, aversion of basic risk factors and how to forestall transmission to other people if they are ongoing carriers of $\mathrm{VH}$.

An adult aged 27 to 40 had more noteworthy openness to $\mathrm{VH}$ infection risk factors and along these lines could be explicit focuses for wellbeing programming. They are in the functioning age bunch and are frequently the essential generators for their family's pay. Early disease and passing related to $\mathrm{VH}$ infection in this group would seriously affect public monetary development. Since numerous in this group have the buying ability to purchase the vaccine, mindfulness projects can acquaint youthful and moderately aged adults with VH infection screening and immunization. This survey had a few merits and constraints. Risk factors depended on self-report and could be underreported because of subjects neglecting or not having any desire to communicate bothersome practices. We picked these risk factors based off of past logical writing, yet this survey did not straightforwardly survey genuine openness to $\mathrm{VH}$, thus we didn't quantify the commitment of each risk factor to $\mathrm{VH}$ infection burden inside the country. The strength of this survey is that we endeavored an arbitrary determination from the populace and, hence, have high trust in the capacity of our outcomes, to sum up to the number of inhabitants in Sokoto. In any case, the populace may differ altogether from others in Sokoto and other countries of the world.

\section{CONCLUSION}

This survey uncovers that the most widely recognized risk factors identified with $\mathrm{VH}$ were sharing nail cutters, having body piercings, and utilizing razor blades. Being male, married, aged 27 to 40 years, and not having a university degree were all essentially identified with more prominent openness to a scope of VH risk factors. These groups can address focuses for future legislative avoidance programs, for instance, $\mathrm{VH}$ infection screening or immunization programs. As Sokoto looks to control VH infection or dispose of it following an objective from the World Health Organization to do as such by 2030, it should create cost-effective answers for the enormous number of $\mathrm{VH}$ carriers in the adult populace.

\section{REFERENCES}

[1] Liu Z, Shi O, Zhang T, Jin L, Chen X: Disease burden of viral hepatitis A, B, C, and E: A systematic analysis. Journal of Viral Hepatitis 2020, 27(12):1284-1296.

[2] Razavi H: Global epidemiology of viral hepatitis. Gastroenterology Clinics 2020, 49(2):179-189. 
[3] Ringehan M, McKeating JA, Protzer U: Viral hepatitis and liver cancer. Philosophical Transactions of the Royal Society B: Biological Sciences 2017, 372(1732):20160274.

[4] Lanini S, Ustianowski A, Pisapia R, Zumla A, Ippolito G: Viral hepatitis: etiology, epidemiology, transmission, diagnostics, treatment, and prevention. Infectious Disease Clinics 2019, 33(4):1045-1062.

[5] Chilaka VN, Konje JC: Viral Hepatitis in pregnancy. European Journal of Obstetrics \& Gynecology and Reproductive Biology 2021, 256:287296.

[6] Smith JW, Kroker-Lobos MF, Lazo M, Rivera-Andrade A, Egner PA, Wedemeyer H, Torres O, Freedman ND, McGlynn KA, Guallar E: Aflatoxin and viral hepatitis exposures in Guatemala: molecular biomarkers reveal a unique profile of risk factors in a region of high liver cancer incidence. PLoS One 2017, 12(12):e0189255.

[7] Reimer J, Lorenzen J, Baetz B, Fischer B, Rehm J, Haasen C, Backmund M: Multiple viral hepatitis in injection drug users and associated risk factors. Journal of gastroenterology and hepatology 2007, 22(1):80-85.

[8] Matos MAd, França DDdS, Carneiro MAdS, Martins RMB, Kerr LRFS, Caetano KAA, Pinheiro RS, Araújo LAd, Mota RMS, Matos MADd: Viral hepatitis in female sex workers using the RespondentDriven Sampling. Revista de saude publica 2017, 51:65.

[9] Hayes MO, Harkness GA: Body piercing as a risk factor for viral hepatitis: an integrative research review. American journal of infection control 2001, 29(4):271-274.

[10] Omote V, Ukwamedua HA, Bini N, Etaghene J, Omoviye EO, Iloka MO: Awareness, Risk Factors and Prevalence of Viral Hepatitis B and $\mathrm{C}$ among Antenatal Attendees in South-southern Nigeria: A Crosssectional and Hospital-based Study. American Journal of Public Health 2020, 8(6):202-208.

[11] Gheorghe L, Csiki IE, Iacob S, Gheorghe C, Smira G, Regep L: The prevalence and risk factors of hepatitis $\mathrm{C}$ virus infection in an adult population in Romania: a nationwide survey 2006-2008. Journal of Gastrointestinal \& Liver Diseases 2010, 19(4).

[12] Kay M: Hepatitis outbreak is traced to contaminated needles and barbershop razors, study shows. BMJ: British Medical Journal (Online) 2012, 345 .

[13] Wang CC, Cheng PN, Kao JH: Systematic review: chronic viral hepatitis and metabolic derangement. Alimentary pharmacology \& therapeutics 2020, 51(2):216-230.

[14] Adesina E, Oyero O, Okorie N, Ben-Enukora C, Adeyeye B: Risk communication for viral hepatitis management among migrants. In: Handbook of research on the global impact of media on migration issues. edn.: IGI Global; 2020: 235-252.

[15] Abarike M: Risk Factors and Prevalence of HIV, Viral Hepatitis B and $\mathrm{C}$ among Patients in General Hospital Lapai, Niger State. Nigerian Journal of Science Vol 2020, 54(1):137-145.

[16] WHO: Combating hepatitis B and C to reach elimination by 2030 : advocacy brief. In.: World Health Organization; 2016.

[17] Link BG, Phelan J: Social conditions as fundamental causes of health inequalities. Handbook of medical sociology 2010, 6:3-17.

[18] Koblin BA, Mccusker J, Lewis BF, Sullivan JL: Racial/ethnic differences in HTV-1 seroprevalence and risky behaviors among intravenous drug users in a multisite study. American Journal of Epidemiology 1990, 132(5):837-846.

[19] Nanbur S, Ajayi AD, Andy E, Daniel G, Solomon GM, Oyedele EA, Goshit JD, Nannim N, Joseph MM: Prevalence of Hepatitis B Surface Antiginaemia and Risk Behaviour Among Youths in Kwanpe Community of Lantang North, Plateau State, Nigeria. 2015.

[20] Goh K, Ding J, Monteiro E, Oon C: Hepatitis B infection in households of acute cases. Journal of Epidemiology \& Community Health 1985, 39(2):123-128.

[21] Limentani A, Elliott L, Noah N, Lamborn J: An outbreak of hepatitis B from tattooing. The Lancet 1979, 314(8133):86-88.

[22] Szmuness W, Much MI, Prince AM, Hoofnagle JH, Cherubin CE, Harley EJ, Block GH: On the role of sexual behavior in the spread of hepatitis B infection. Annals of internal medicine 1975, 83(4):489495.

[23] Martinson FE, Weigle KA, Royce RA, Weber DJ, Suchindran CM, Lemon SM: Risk factors for horizontal transmission of hepatitis B virus in a rural district in Ghana. American Journal of Epidemiology 1998, 147(5):478-487.

[24] Lawal MA, Adeniyi OF, Akintan PE, Salako AO, Omotosho OS, Temiye EO: Prevalence of and risk factors for hepatitis $\mathrm{B}$ and $\mathrm{C}$ viral co-infections in HIV infected children in Lagos, Nigeria. PLoS One 2020, 15(12):e0243656.

[25] Anyanwu NCJ, Sunmonu PT, Mathew MH: Viral hepatitis B and C co-infection with Human Immunodeficiency Virus among adult patients attending selected highly active anti-retroviral therapy clinics in Nigeria's capital. Journal of Immunoassay and Immunochemistry 2020, 41(2):171-183.

[26] Oliveira MDdS, Matos MA, Martins RM, Teles SA: Tattooing and body piercing as lifestyle indicator of risk behaviors in Brazilian adolescents. European journal of epidemiology 2006, 21(7):559-560.

[27] Jimenez AP, El-Din NS, El-Hoseiny M, El-Daly M, Abdel-Hamid M, El Aidi S, Sultan Y, El-Sayed N, Mohamed MK, Fontanet A: Community transmission of hepatitis B virus in Egypt: results from a case-control study in Greater Cairo. International journal of epidemiology 2009, 38(3):757-765.

[28] Luksamijarulkul P, Maneesri P, Kittigul L: Hepatitis B seroprevalence and risk factors among school-age children in a low socioeconomic community, Bangkok. Asia Pacific Journal of Public Health 1995, 8(3):158-161.

[29] Yakasai IA, Ayyuba R, Abubakar I, Ibrahim S: Sero-prevalence of hepatitis $\mathrm{B}$ virus infection and its risk factors among pregnant women attending antenatal clinic at Aminu Kano Teaching Hospital, Kano, Nigeria. Journal of Basic and Clinical Reproductive Sciences 2012, 1(1-2):49-55.

[30] Adesina E, Oyero O, Okorie N, Amodu L, Adeyeye B, Yartey D: Data on information sources, knowledge and practice on hepatitis B virus in Southwest Nigeria. Data in brief 2020, 30:105507.

[31] Ogbonna C, Ogoke C, Ikefuna A, Ezeofor T, Nwolisa E: Risk Factors, Sero-prevalence and Infectivity of Hepatitis B Virus amongst Children Resident in Orphanages in a Develop-ing Country. J Infect Dis Epidemiol 2021, 7:186. 